\title{
Impact of Covid-19 Pandemic on Mental Health among Bangladeshi Senior Citizens: A Cross-Sectional Study
}

\author{
* Mohammad Shahadat Hossen ${ }^{1}$, Abu Hayat Md Rafiqul Rezvi²
}

1 PhD student, Faculty of Human Ecology, University Putra Malaysia (UPM),, Malaysia, Email: shahadatupm@gmail.com

${ }^{2}$ Research Consultant, Rafiquaila Richwell Research Enterprise, Malaysia.

Email: rafiqul.rezvi@gmail.com

*Corresponding author
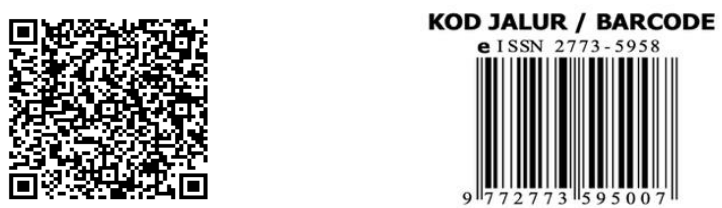

\author{
Date Received: 1 March 2021 \\ Date Accepted: 15 March 2021 \\ Date Online Published: 4 April 2021 \\ Volume- 2, Issue- 2, May 2021 \\ (๑) ICRRD HIGH INDEX RESEARCH JOURNAL.
}

Abstract: Novel Coronavirus (COVID-19) is a dangerous virus that was first emerged in China at December 2019. It has already infected more than 128 million people and killed more than 2.8 million people. The main purpose of this paper is to find out the present mental condition of Bangladeshi Senior Citizens in Dhaka city to overcome their loneliness or boringness. A systematic cross sectional online survey regarding COVID-19 has been conducted from June 15 to June 25, 2020. After developing questionnaires utilizing Google form, it has been sent out to the participants using online platform and the responses of the participants have been recorded. Total 280 participants (100 female and 180 male) completed the survey. The average age of them is about 60 years. It has been observed that maximum male participants (58.3\%) felt financial stress and maximum female participants (56\%) felt horrified due to COVID-19. Additionally, it has been found that maximum male and female participants were utilized more time in the social media then the normal time. Since COVID-19 has already become a major issue all over the world, it is necessary to identify the mental health conditions and activities of people during this pandemic situation so that appropriate measures can be taken. More research should be conducted regarding mental health impact and possible solution. Hopefully, it will ease to provide fruitful information especially for the community health workers with a view to helping them tackle these psychological fitness related issues in response to other similar societal disasters. After the pandemic, follow-up should be made in order to improve mental health.

Keywords: Mental condition, Questionnaires, Stress, Boringness, Participants. 


\section{INTRODUCTION}

After December 2019, the world has observed a huge epidemic of pneumonia for an unexplained aetiology, which first occurred in the province of Wuhan, China [1]. Following this epidemic, the World Health Organization (WHO) has identified SARS CoV-2 as a novel corona virus as a pandemic causative in China and elsewhere in the world [2]. By 12 February 2020, COVID-19 had been unquestionably recorded to be 43,103, of which 42,708 had come from China (99.1\%) [3]. Those analyses have clearly demonstrated that the COVID-19, which was described as a global public health catastrophe, has impacted China seriously [4]. The COVID-19 signs are associated with similar extreme respiratory syndrome (SARS), which can spread enormously from animals to humans [5]. In view of the present situation, whether the pandemic reaches its height is always unambiguous. The SARS-CoV-2 origins remains unknown. However, in Wuhan, where certain wildlife species, including bats, were illegal sellers, Sarst COV-2 was first contaminated with touch from the local seafood vendor [6]. It is also interesting to consider how the longevity of the COVID-19 pandemic takes place with a deadly virus, in particular in the highly infected countries, such as China. The predicted COVID-19 destruction is directly associated with the 2003 SARS epidemic. More than 8000 SARS infections and 800 deaths occurred in 26 countries across the world [7, 8]. The outbreak of SARS (by July 2003) took eight months to contain [2]. In areas significantly impacted by the SARS outbreak, moderate to extreme post-traumatic stress symptoms were found [9] among the community. Taking into consideration risk factors, the risk for SARS-related post-traumatic stress symptoms was more vulnerable for women [9].

In addition, MERS, H1N1 and Ebola pandemics have also had an impact on mental wellbeing, including sensational depression and the issue with the usage of substances [8]. There may also have been several apparent trigger factors for anxiety and depression in the community, including high mortality rates, food shortages and property, discrepancy between citizens and experiences with infected and weak people, which may lead to some undesirable psychological conditions during this epidemic [8]. In the opposite, in the course of the beginning of the epidemic in December 2019 there were about 82,000 cases of VCOVID-19 with > 2,800 deaths [2].

A number of scholars have recently focused on different COVID-19 viewpoints. In using the SIR model [10] Ozdinc et al. projected COVID-19 improvement. Otolaryngology-Head and Neck Surgery Outlook of COVID-19 [11] reviewed by Sayin et Al. To approximate the instantaneous R for COVID-19, Senel et al. performed Bayesian statistical inference [12]. Furthermore, Toluk et al. also examined COVID-19 statistics [13]. Akgül used online media during COVID-19 to have counselling [14]. In addition, Rabby et al study's on the general interpretation of COVID-19 was carried out online [15]. The study on COVID19 also was carried out by Ahmadian et al. and Serdaroğlu et al. [16, 17]. Clinical symptoms of COVID19 patients recorded on the clinical symptoms of COVID-19 patients and articulated quantitative estimates of the unintended distribution of COVID-19 [18, 19] were also analysed [18, 19]. In the meantime, several works examined the efficacy of COVID-19 drugs [20-22]. However, there are insufficient research on the serious effect on mental wellbeing of a COVID-19 pandemic as well as on lonely or tedious behaviors. 
The main purpose of the study is to investigate if the COVID-19 pandemic has rapidly had an effect on mental wellbeing, including lifestyle standards. This research centred on the senior citizens of Bangladesh in the city of Dhaka. With successful survey and many case studies, the present psychological condition of the senior citizen of Dhaka was demonstrated. However, in this critical moment to combat the pandemic of psychological effectiveness, this research would be able to draw the attention of the authority concerned to take the necessary measures to properly care senior citizens.

This report would also enable other countries take adequate consideration of the emotional condition of their population.

\section{MATERIALS AND METHODS}

From 15 January 2021 to 25 February 2021, a cross sectional analysis was accomplished. Only senior citizens (aged $\geq 50$ years) who had the ability to share verbal consent were selected in the study and convenience and snowball sampling methods was applied successfully. Additionally, all of the participants were senior citizens in Bangladesh. For completing the survey, no monetary rewards were provided regarding promotional activities. Since community-based national sampling survey has become very difficult due to the locked down situation, that's why necessary data has been collected utilizing online platform. A Google form has been created with necessary questionnaires and forwarded to the participants through Messenger and WhatsApp account. The survey mainly consisted of two main questionnaires to find out how the mental health of the participants were affected due to COVID-19 and how they were trying to overcome their loneliness or boringness. Moreover, both male and female participants were participated, and they were required to indicate there gender. The findings from the survey presented in Table 1 and 2.

\section{RESULTS}

Table 1 demonstrates negative mental health impacts by demographic factors and Table 2 exhibits activities to overcome loneliness or boringness by demographic factors.

Table 1. Negative mental health impacts by demographic factors.

\begin{tabular}{|l|l|l|l|l|l|l|}
\hline Variables & \multicolumn{2}{|l|}{ Sex $(\mathbf{n}=280)$} & \multicolumn{3}{|l|}{ Education status (n=280) } \\
\cline { 2 - 7 } & $\begin{array}{l}\text { Females(n=1 } \\
\text { 80) }\end{array}$ & $\begin{array}{l}\text { Males } \\
\mathbf{1 0 0})\end{array}$ & $\begin{array}{l}\text { Bachelor } \\
(\mathbf{n = 1 1 0})\end{array}$ & $\begin{array}{l}\text { Masters } \\
(\mathbf{n = 8 0})\end{array}$ & $\begin{array}{l}\text { PhD } \\
(\mathbf{n = 1 0})\end{array}$ & $\begin{array}{l}\text { Others } \\
(\mathbf{n}=\mathbf{8 0})\end{array}$ \\
\hline $\begin{array}{l}\text { Increased stress } \\
\text { from fear, n (\%) }\end{array}$ & & & & & & \\
Yes & $43(23.9)$ & $27(27)$ & $23(20.9)$ & $12(15)$ & $5(50)$ & $15(18.7)$ \\
No & $137(76.1)$ & $73(73)$ & $87(79.1)$ & $68(85)$ & $5(50)$ & $65(81.3)$ \\
\hline $\begin{array}{l}\text { Increased } \\
\text { financial stress, n }\end{array}$ & $105(58.3)$ & $55(55)$ & $60(54.5)$ & $47(58.8)$ & $6(60)$ & $50(62.5)$ \\
$(\%)$ & $75(41.7)$ & $45(45)$ & $50(45.5)$ & $33(41.2)$ & $4(40)$ & $30(37.5)$ \\
Yes & & & & & & \\
No & & & & & & \\
\hline
\end{tabular}




\begin{tabular}{|c|c|c|c|c|c|c|}
\hline $\begin{array}{l}\text { Increased stress } \\
\text { from home, n } \\
(\%) \\
\text { Yes } \\
\text { No }\end{array}$ & $\begin{array}{l}96(53) \\
84(47)\end{array}$ & $\begin{array}{l}51(51) \\
49(49)\end{array}$ & $\begin{array}{l}61(55.5) \\
49(44.5)\end{array}$ & $\begin{array}{l}39(48.7) \\
41(51.3)\end{array}$ & $\begin{array}{l}4(40) \\
6(60)\end{array}$ & $\begin{array}{l}38(47.5) \\
42(52.5)\end{array}$ \\
\hline $\begin{array}{l}\text { Increased stress } \\
\text { from family } \\
\text { members, n }(\%) \\
\text { Yes } \\
\text { No }\end{array}$ & $\begin{array}{l}96(53) \\
84(47)\end{array}$ & $\begin{array}{l}51(51) \\
49(49)\end{array}$ & $\begin{array}{l}61(55.5) \\
49(44.5)\end{array}$ & $\begin{array}{l}39(48.7) \\
41(51.3)\end{array}$ & $\begin{array}{l}3(30) \\
7(70)\end{array}$ & $\begin{array}{l}38(47.5) \\
42(52.5)\end{array}$ \\
\hline $\begin{array}{l}\text { Feel horrified, } \\
\text { n }(\%) \\
\text { Yes } \\
\text { No }\end{array}$ & $\begin{array}{l}94(52.2) \\
86(47.4)\end{array}$ & $\begin{array}{l}56(56) \\
44(44)\end{array}$ & $\begin{array}{l}51(46.4) \\
59(53.6)\end{array}$ & $\begin{array}{l}46(57.5) \\
34(42.5)\end{array}$ & $\begin{array}{l}6(60) \\
4(40)\end{array}$ & $\begin{array}{l}47(58.8) \\
33(41.2)\end{array}$ \\
\hline $\begin{array}{l}\text { Feel helpless, } \\
\text { n (\%) } \\
\text { Yes } \\
\text { No }\end{array}$ & $\begin{array}{l}99(55) \\
81(45)\end{array}$ & $\begin{array}{l}49(49) \\
51(51)\end{array}$ & $\begin{array}{l}49(44.5) \\
61(55.5)\end{array}$ & $\begin{array}{l}45(56.3) \\
35(43.7)\end{array}$ & $\begin{array}{l}3(30) \\
7(70)\end{array}$ & $\begin{array}{l}40(50) \\
40(50)\end{array}$ \\
\hline $\begin{array}{l}\text { Feel } \\
\text { apprehensive, n } \\
(\%) \\
\text { Yes } \\
\text { No }\end{array}$ & $\begin{array}{l}78(43.3) \\
102(56.7)\end{array}$ & $\begin{array}{l}39(39) \\
61(61)\end{array}$ & $\begin{array}{l}41(37.3) \\
69(62.7)\end{array}$ & $\begin{array}{l}38(47.5) \\
42(52.5)\end{array}$ & $\begin{array}{l}4(40) \\
6(60)\end{array}$ & $\begin{array}{l}55(68.8) \\
25(31.25)\end{array}$ \\
\hline
\end{tabular}

Table 2. Activities to overcome loneliness or boringness by demographic factors.

\begin{tabular}{|l|l|l|l|l|l|l|}
\hline Variables & \multicolumn{2}{|l|}{ Sex $(\mathbf{n}=280)$} & \multicolumn{4}{|l|}{ Education status (n=280) } \\
\cline { 2 - 7 } & $\begin{array}{l}\text { Females(n=1 } \\
\mathbf{8 0})\end{array}$ & $\begin{array}{l}\text { Males } \\
(\mathbf{n = 1 0 0})\end{array}$ & $\begin{array}{l}\text { Bachelor } \\
(\mathbf{n = 1 1 0})\end{array}$ & $\begin{array}{l}\text { Masters } \\
(\mathbf{n = 8 0})\end{array}$ & $\begin{array}{l}\text { PhD } \\
(\mathbf{n = 1 0})\end{array}$ & $\begin{array}{l}\text { Others } \\
(\mathbf{n = 8 0})\end{array}$ \\
\hline $\begin{array}{l}\text { Watching } \\
\text { movie/ drama/ } \\
\text { YouTube, } \\
\text { n (\%) }\end{array}$ & & & & & & \\
Yes & $87(48,3)$ & $64(64)$ & $56(50.9)$ & $43(53.8)$ & $3(30)$ & $12(15)$ \\
No & $93(51.7)$ & $36(36)$ & $54(49.1)$ & $37(46.2)$ & $7(70)$ & $68(85)$ \\
\hline $\begin{array}{l}\text { Using social } \\
\text { media more, n } \\
(\%)\end{array}$ & $111(61.7)$ & $65(65)$ & $66(60)$ & $58(72.5)$ & $4(40)$ & $47(58.8)$ \\
Yes & $69(38.3)$ & $35(35)$ & $44(40)$ & $22(27.5)$ & $6(60)$ & $33(41.2)$ \\
№ & & & & & \\
\hline
\end{tabular}




\begin{tabular}{|c|c|c|c|c|c|c|}
\hline $\begin{array}{l}\text { Gossiping with } \\
\text { family member, } \\
\text { n (\%) } \\
\text { Yes } \\
\text { No }\end{array}$ & $\begin{array}{l}84(47) \\
96(53)\end{array}$ & $\begin{array}{l}42(42) \\
58(58)\end{array}$ & $\begin{array}{l}56(50.9) \\
54(49.1)\end{array}$ & $\begin{array}{l}36(45) \\
44(55)\end{array}$ & $\begin{array}{l}6(60) \\
4(40)\end{array}$ & $\begin{array}{l}39(48.7) \\
41(51.3)\end{array}$ \\
\hline $\begin{array}{l}\text { Performing } \\
\text { more prayer to } \\
\text { God, n }(\%) \\
\text { Yes } \\
\text { No }\end{array}$ & $\begin{array}{l}73(40.6) \\
107(59.4)\end{array}$ & $\begin{array}{l}54(54) \\
46(46)\end{array}$ & $\begin{array}{l}39(35.5) \\
71(64.5)\end{array}$ & $\begin{array}{l}56(70) \\
24(30)\end{array}$ & $\begin{array}{l}8(80) \\
2(20)\end{array}$ & $\begin{array}{l}39(48.7) \\
41(51.3)\end{array}$ \\
\hline $\begin{array}{lr}\text { Playing } & \text { online } \\
\text { and } & \text { mobile } \\
\text { games, } & \\
\text { n (\%) } & \\
\text { Yes } & \\
\text { No } & \end{array}$ & $\begin{array}{l}\text { 109(60.6) } \\
71(39.4)\end{array}$ & $\begin{array}{l}56(56) \\
44(44)\end{array}$ & $\begin{array}{l}54(49.1) \\
56(50.9)\end{array}$ & $\begin{array}{l}57(71.3) \\
23(28.7)\end{array}$ & $\begin{array}{l}3(30) \\
7(70)\end{array}$ & $\begin{array}{l}46(57.5) \\
34(42.5)\end{array}$ \\
\hline $\begin{array}{l}\text { Performing } \\
\text { physical } \\
\text { exercise, } \\
\text { n (\%) } \\
\text { Yes } \\
\text { No }\end{array}$ & $\begin{array}{l}98(54.4) \\
82(45.6)\end{array}$ & $\begin{array}{l}45(45) \\
55(55)\end{array}$ & $\begin{array}{l}56(50.9) \\
54(49.1)\end{array}$ & $\begin{array}{l}36(45) \\
44(45)\end{array}$ & $\begin{array}{l}8(80) \\
2(20)\end{array}$ & $\begin{array}{l}45(56.3) \\
35(43.7)\end{array}$ \\
\hline
\end{tabular}

\section{DISCUSSION}

Among 280 participants, 180 were female and 100 were male. Based on the education status, it has been observed that 110 participants were from Bachelor's level, 80 participants were from Master's level, 10 participants were from $\mathrm{PhD}$ and 80 participants were from other level.

First of all, negative mental health impacts can be compared. Based on gender, it has been observed that majority (56\%) of the male participants felt horrified due to the COVID-19 and majority (58.3\%) of the female participants felt excessive financial stress due to COVID-19. Moreover, majority of male participants felt excessive financial stress, excessive stress from home, and excessive stress from family members $(55 \%, 51 \%$, and $51 \%$ respectively). However, the majority of male participants did not feel stress from fear, helpless and apprehensive. In case of female participants, though majority of the participants felt excessive stress from home and family, felt horrified and helpless, still majority did not feel excessive stress from fear and apprehensive.

Based on education status, it has been observed that majority (55.5\%) of the participants from Bachelor's level felt reported increment of stress from and family members due to COVID-19. Majority of the same level also reported increment of financial stress but majority did not feel increment of stress from fear and did not feel horrified, helpless, and apprehensive. On the other hand, maximum master's level 
participants $(58.8 \%)$ reported increment of financial stress. Majority of the same level also felt horrified and helpless but majority did not feel increment stress from fear, home, and family members and did not feel apprehensive. On the contrary, maximum participants $(60 \%)$ from $\mathrm{PhD}$ level felt increment of financial stress and horrified due to COVID-19. Moreover, majority of the same level felt increment of stress from fear but did not feel helpless, apprehensive and did not feel increment of stress from home and family members.

Secondly, activities to overcome loneliness or boringness can be compared.

Based on gender, it has been observed that majority $(65 \%)$ of the male participants used social media more to overcome loneliness or boringness. Similarly, maximum (61.7\%) of the female participants reported that they used social media more. Though majority of male participants watched movie/ drama/ YouTube, performed more prayer to God and played online and mobile games, majority did not gossip with family members and did not perform physical exercise. Moreover, majority of female participants played online and mobile games and performed physical exercise. However, the majority of female participants did not watch movie/ drama/ YouTube, did not gossip with family members and performed less prayer to God.

Based on education status, it has been found that majority $(60 \%)$ of the participants from Bachelor's level used social media more. Moreover, majority of the same level watched movie/ drama/ YouTube, gossiped with family members and performed physical exercise but majority did not perform prayer to God and did not play online and mobile games. Similarly, maximum master's level participants $(72.5 \%)$ reported that they used social media more. Majority of the same level also watched movie/ drama/ YouTube, perform prayer to God and played online and mobile games but majority did not gossip with family members and did not perform physical exercise. On the other hand, maximum participants $(80 \%)$ from $\mathrm{PhD}$ level performed prayer to God and performed physical exercise. Majority of the same level also gossiped with family members but majority did not watch movie/ drama/ YouTube, use social media for a long time and played online and mobile games.

The study is one of the investigations in order to find out the harmful effects caused by the COVID-19 pandemic on mental health of Bangladeshi International student of Malaysia. Though concerned authority is very alarming and trying to take necessary steps, the pandemic is still increasing and more countries are affected which make the participants horrified. Due to locked down condition, income becomes difficult that's why financial stress has been arisen. As the parents and relatives of the participants are living in other countries and whole world have been affected by the COVID-19 pandemic, that's why participants also feeling stress. As no vaccine has been discovered yet in order to tackle COVID-19 virus, participants are feeling helpless.

\section{CONCLUSION}

As COVID-19 is a global issue, appropriate steps should be taken as early as possible. Further studies on mental wellbeing consequences and alternative remedies can be carried out. In order to help them overcome these problems of psychological readiness in reaction to similar social tragedy, it would be 
anticipated that fruitful information will be given, particularly for community healthcare staff. Followup can be done to boost emotional wellbeing after the pandemic.

\section{ACKNOWLEDGEMENT}

The corresponding author wants to thank all the participants for their valuable responses.

\section{FUNDING}

The author(s) received no financial support for the research, authorship and publication of this article.

\section{CONFLICTS OF INTEREST}

On behalf of all authors, the corresponding author states that there is no conflict of interest.

\section{DECLARATIONS}

The manuscript has not been submitted in any other journal or conference.

\section{ETHICAL CONSIDERATIONS}

Confidentiality of the study participants' information was maintained throughout the study by making the participants' information anonymous and asking the participants to provide honest answers. Eligible participator's participation in this survey was voluntary and was not compensated. Informed consent was obtained from each participant prior to participation. The study was performed following the Helsinki Declaration as revised in 2013. The study was conducted following the Checklist for Reporting Results of Internet E-Surveys (CHERRIES) guidelines. Moreover, all the collected data through this survey is inserted in result section.

\section{REFERENCES}

Wuhan Municipal Health Commission. Wuhan Municipal Health Commission's Briefing on the Pneumonia Epidemic Situation. Available online: http://wjw.wuhan.gov.cn/front/web/showDetail/2019123108989 (accessed on 31 May 2019).

Wilder-Smith A, Chiew CJ, Lee VJ. Can we contain the COVID-19 outbreak with the same measures as for SARS?. The Lancet Infectious Diseases. 2020 Mar 5. https://doi.org/10.1016/S1473-3099(20)30129-8. WHO. Novel Coronavirus (2019-ncov) Situation Report-22 Situations; WHO: Geneva, Switzerland, 2020.

Hui DS. I Azhar E, Madani TA, Ntoumi F, Kock R, Dar O, Ippolito G, Mchugh TD, Memish ZA, Drosten C, Zumla A, Petersen E. The continuing 2019-nCoV epidemic threat of novel coronaviruses to global health-The latest 2019 novel coronavirus outbreak in Wuhan, China. Int J Infect Dis. 2020 Feb;91:2646. https://doi.org/10.1016/j.ijid.2020.01.009. 
Stop the Wuhan virus. Nature. 2020 Jan;577(7791):450. doi: https://doi.org/10.1038/d41586-020-00153-x.

Wang W, Tang J, Wei F. Updated understanding of the outbreak of 2019 novel coronavirus (2019-nCoV) in Wuhan, China. Journal of medical virology. 2020 Apr;92(4):441-7. https://doi.org/10.1002/jmv.25689.

Graham RL, Donaldson EF, Baric RS. A decade after SARS: strategies for controlling emerging

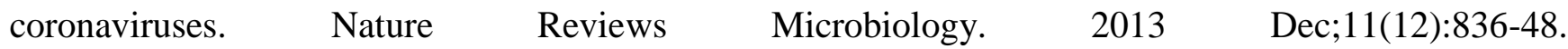
https://doi.org/10.1038/nrmicro3143.

Brooks SK, Webster RK, Smith LE, Woodland L, Wessely S, Greenberg N, Rubin GJ. The psychological impact of quarantine and how to reduce it: rapid review of the evidence. The Lancet. 2020 Feb 26. https://doi.org/10.1016/S0140-6736(20)30460-8.

Lau JT, Yang X, Pang E, Tsui HY, Wong E, Wing YK. SARS-related perceptions in Hong Kong. Emerging infectious diseases. 2005 Mar;11(3):417. https://doi.org/10.3201/eid1103.040675.

Ozdinc M, Senel K, Ozturkcan S, Akgul A. Predicting the progress of COVID-19: the case for Turkey. Turkiye Klinikleri Journal of Medical Sciences. 2020 April 24;40(2):117-119. https://doi.org/10.5336/medsci.2020-75741.

Sayin İ, Yazici ZM, Öz F, Akgül A. Otolaryngology-Head and Neck Surgery Perspective of COVID-19. Turkiye Klinikleri Journal of Medical Sciences. 2020 April 14;40(2):120-124. https://doi.org/10.5336/medsci.2020-75313.

Senel K, Özdinc M, Ozturkcan S, Akgul A. Instantaneous R for COVID-19 in Turkey: Estimation by Bayesian Statistical Inference. Turkiye Klinikleri Journal of Medical Sciences. 2020 June 1;40(2):127131. https://doi.org/10.5336/medsci.2020-76462.

Toluk Ö, Çakmak BD, Ercan İ, Uncu Y. Analysis from Statistical Perspective of 2019 Novel Coronavirus Cases in Turkey: How are the Things Going on?. Turkiye Klinikleri Journal of Medical Sciences. 2020 May 5;40(2):228-235. https://doi.org/10.5336/medsci.2020-75704.

Akgül A. Online Counselling for New Onset Symptoms/Signs in 65+ Patients with Lympho-Venous Diseases in the Era of COVID-19. Turkiye Klinikleri Journal of Medical Sciences. 2020 May 23;40(2):125-126. https://doi.org/10.5336/medsci.2020-76613.

Rabby MII, Hossain F, Akhi IJ, Amin SAMS, Khan Ayman. Understanding of General People about COVID-19: A Cross-Sectional Online Survey and Qualitative Presentation. Turkiye Klinikleri Journal of Medical Sciences. 2020 May 8;40(2):203-219. https://doi.org/10.5336/medsci.2020-75605.

Ahmadian R, Uncu Y, Ercan İ. Turkey in Between European Union Countries in the New Coronavirus (COVID-19) Outbreak; An Examination of the Doubling Times. Turkiye Klinikleri Journal of Medical Sciences. 2020 April 29;40(2):220-227. https://doi.org/10.5336/medsci.2020-75702. 
Serdaroğlu E, Serdaroğlu A. COVID-19 and Neurological Manifestations. Turkiye Klinikleri Journal of Medical Sciences. 2020 May 17;40(2):269-271. https://doi.org/10.5336/medsci.2020-76093.

Chan JF, Yuan S, Kok KH, To KK, Chu H, Yang J, Xing F, Liu J, Yip CC, Poon RW, Tsoi HW. A familial cluster of pneumonia associated with the 2019 novel coronavirus indicating person-to-person transmission: a study of a family cluster. The Lancet. 2020 Feb 15;395(10223):514-23. https://doi.org/10.1016/S0140-6736(20)30154-9.

Huang C, Wang Y, Li X, Ren L, Zhao J, Hu Y, Zhang L, Fan G, Xu J, Gu X, Cheng Z. Clinical features of patients infected with 2019 novel coronavirus in Wuhan, China. The Lancet. 2020 Feb 15;395(10223):497-506. https://doi.org/10.1016/S0140-6736(20)30183-5.

Rabby MI. Current Drugs with Potential for Treatment of COVID-19: A Literature Review. Journal of Pharmacy \& Pharmaceutical Sciences. 2020 Apr 4;23(1):58-64. https://doi.org/10.18433/jpps31002.

Rosa SG, Santos WC. Clinical trials on drug repositioning for COVID-19 treatment. Revista Panamericana de Salud Pública 2020;44. https://doi.org/10.26633/RPSP.2020.40.

Hançer AT, Yilmaz P, Yilmaz M. New Coronavirus (2019-nCoV/COVID-19) and Vitamin C. Türkiye Klinikleri Journal of Medical Sciences. 2020 May 10;40(2):260-264. https://doi.org/10.5336/medsci.2020-76024. 